\title{
A Case of Diffuse Large B-Cell Lymphoma Mimicking Primary Effusion Lymphoma-Like Lymphoma
}

\author{
Daisuke Usuda $^{\mathrm{a}, \mathrm{b}} \quad$ Masahisa Arahata ${ }^{c}$ Kento Takeshima ${ }^{\mathrm{b}}$ \\ Ryusho Sangen $^{\mathrm{b}}$ Akiteru Takamura ${ }^{\mathrm{b}}$ Yasuhiro Kawai $^{\mathrm{a}}$ Yuji Kasamaki $^{\mathrm{b}}$ \\ Yoshitsugu Iinuma $^{a}$ Tsugiyasu Kanda ${ }^{b}$ \\ ${ }^{a}$ Department of Infectious Diseases, Kanazawa Medical University, Uchinada, Japan; \\ ${ }^{b}$ Department of Community Medicine, Kanazawa Medical University Himi Municipal \\ Hospital, Himi, Japan; 'Department of Internal Medicine, Nanto Municipal Hospital, \\ Nanto, Japan
}

\section{Keywords}

Diffuse large B-cell lymphoma · Pericardial effusion · Pleural effusion · Primary effusion lymphoma-like lymphoma $\cdot$ Diagnosis

\begin{abstract}
A 93-year-old female was transferred to the emergency ward of our hospital due to disturbance of consciousness and hypotension. Computed tomography showed bilateral pleural and pericardial effusion without evidence of tumor masses or lymphadenopathy. Cytodiagnosis of pleural effusion revealed proliferation of atypical lymphoid-like cells with pan-B surface markers. We suspected primary effusion lymphoma-like lymphoma; however, the monoclonality of these cells was not confirmed. Cytodiagnosis of bone marrow revealed lymphoma cells with monoclonal B-cell markers. These findings prompted a diagnosis of diffuse large Bcell lymphoma with bone marrow invasion. In the case of pericardial or pleural effusion, clinicians should consider carefully both hematological malignancy and its classification.
\end{abstract}




\section{Case Reports in Oncology}

Usuda et al.: A Case of Diffuse Large B-Cell Lymphoma Mimicking Primary Effusion

Lymphoma-Like Lymphoma

\section{Introduction}

Originally described in 1995, primary effusion lymphoma (PEL) is a rare subtype of diffuse large B-cell lymphoma (DLBCL) universally associated with human herpes virus-8 (HHV-8) that involves body cavities and causes serous effusions without detectable masses or lymphadenopathy according to the World Health Organization (WHO) classification of tumors about hematopoietic and lymphoid tissue [1-4]. It occurs mainly in immunocompromised patients infected with human immunodeficiency virus (HIV) and Epstein-Barr virus (EBV) $[2,4,5]$. On the other hand, in Japan, many cases of DLBCL with lymphomatous effusions on serosal surfaces and no detectable mass lesion like PEL have been reported. These cases were not regarded as cases of PEL but as a new entity, "PEL-like lymphoma (PEL-LL)" [6].

Herein, we report a case of an elderly female patient with DLBCL with bilateral pleural effusion and massive pericardial effusion. The type of DLBCL was difficult to determine because clinical features and several findings of examinations resembled PEL or PEL-LL; however, the patient's hematological findings could not be diagnosed as both.

\section{Case Report}

A 93-year-old female was transferred to the emergency ward of our hospital due to disturbance of consciousness and hypotension. Her medical history included gastric tube feeding due to cerebral infarction and disuse syndrome, complicated by hypertension, atrial fibrillation, chronic renal insufficiency, and constipation. She was under treatment with antiplatelet, antihypertensive, and cathartic medications. She had been bedridden for a number of years and had received regular medical and nursing care at home. When the ambulance call to render medical assistance arrived at her home, she had fully recovered her consciousness, her blood pressure was within normal limits, and she did not complain of B symptoms.

In the emergency room, she presented with mild disturbance of consciousness (Ja pan coma scale 1), irregular pulse rate, and mild pitting edema to bilateral lower legs. She was negative for lymphadenopathy and hepatosplenomegaly. Urinalysis showed asymptomatic bacteriuria, and routine blood tests showed normocytic anemia, hypoalbuminemia, and several chemical data such as C-reactive protein, lactate dehydrogenase, creatinine, blood urea nitrogen, potassium, ferritin, and soluble interleukin-2 receptor were elevated. Electrocardiogram showed atrial fibrillation, and carotid ultrasonography showed moderate arteriosclerosis. Computed tomography of her head, neck, chest, and abdomen showed multiple lacunar infarction, bilateral pleural effusion, pericardial effusion, and bilateral renal atrophy. There was, however, no evidence of tumor mass, lymph node enlargement, or hepatosplenomegaly on computed tomography. Echocardiography showed massive pericardial effusion. Examination ruled out heart failure, infectious disease, and collagen disease. The patient was admitted to our hospital for intensive examination and treatment. Pericardial drainage was not performed because she was not in cardiac tamponade and, in addition to this, there was apprehension about iatrogenic damage to her heart. Pleural effusion was revealed to be exudative and seemed to be the cause of the patient's dyspnea. Microscopic 


\section{Case Reports in Oncology}

Case Rep Oncol 2017;10:1013-1022

DOI: $10.1159 / 000484042$

(C) 2017 The Author(s). Published by S. Karger AG, Base www.karger.com/cro

Usuda et al.: A Case of Diffuse Large B-Cell Lymphoma Mimicking Primary Effusion Lymphoma-Like Lymphoma

observation of pleural effusion showed hemophagocytosis as well as proliferation of atypical lymphoid-like blast cells, which were positive for cluster of differentiation (CD) 19, CD20, and CD25 (Fig. 1a, b). Flow cytometry of the cells in pleural effusion was negative for monoclonality in B-lymphocyte fraction. Additionally, evidence of HIV and/or EBV infection was not detected, and cytogenetic analysis for HHV-8 and lymph node biopsy could not be performed. From the above, we suspected malignant lymphoma such as PEL-LL; however, we were unable to arrive at a conclusive diagnosis. Bone marrow examination revealed the same atypical lymphoid-like cells seen in pleural effusion; however, there was no evidence of neoplastic proliferation tumorous growth (Fig. 2a, b). Cell surface antigen analysis of bone marrow cells revealed strong deviation to gamma-chain side in B-lymphocyte fraction, which we suspected was due to neoplastic proliferation tumorous growth (Fig. 2c). Furthermore, because the CD20-positive cell rate was high (approx. 70\%), we suspected that the tumor cells were CD20-positive. Chromosomal abnormality was not confirmed. The above findings prompted a diagnosis of DLBCL with bone marrow invasion rather than PEL-LL.

Considering the patient's age and the side effects of chemotherapy, we administered 8 cycles of chemotherapy with rituximab $375 \mathrm{mg} / \mathrm{m}^{2}$ once per week (Fig. 2). Fortunately, her vital signs improved immediately and her symptoms gradually resolved. Furthermore, we confirmed that her pericardial effusion significantly decreased after 4 cycles of chemotherapy and disappeared after 8 cycles. Judged to have been in complete remission, she was discharged from the hospital on day 109 of hospitalization (Fig. 3). At the 28-month follow-up, the patient remained free of recurrence.

\section{Discussion}

The most significant lesson learned from our experience with the present case is our initial diagnosis of PEL-LL. Actually, the present case had many clinical features mimicking PEL-LL. She suffered from circulatory failure and had massive pericardial fluid with pleural effusion, in which many atypical lymphoid cells were detected. It was our inability to confirm monoclonal B-cell tumor after more careful examination that prompted us to change our diagnosis to DLBCL.

Here, a fundamental question arises as to whether it is possible to diagnose B-cell lymphoma on first observation. The WHO classification proposes that PEL be universally defined as an immune deficiency-related lymphoma and associated with HHV-8 infection [7]. Therefore, our patient's condition could not have been diagnosed as PEL because she had no immunodeficiency. In addition, PEL-LL was not a definite disease unit in the 2016 revision of the WHO classification of lymphoid neoplasms. This should, therefore, be discussed at greater length [8]. HCV, iatrogenic immunodeficiency, alcoholism, liver cirrhosis, cancer, and advanced age have been reported as possible reasons for PEL-LL. PEL-LL affects elderly patients (median age, 74 years) and patients with volume overload such as those with liver cirrhosis $(12 \%)$ or congestive heart failure (5.5\%); and PEL-LL patients have a greater number of CD20-positive cells (86\%) than PEL patients. Additionally, patients with ascites have a higher incidence of HCV infection (39\%) than pericardial effusion $(7 \%)$ or pleural effusion $(9 \%)[2,6,9-11]$. Cytologically, PEL-LL cells resemble the large atypical cells of DLBCL, and 
their neoplastic cells show immunoreactivity for pan-B-cell markers such as CD19, CD20, and CD79a; the lymphoma cells express pan-B-cell antigens in $86.7 \%$, and CD20 is expressed in $71.1 \%$ of the cases. On the other hand, the neoplastic cells in PEL usually lack such immunoreactivity $[3,5,6,9]$. The features of our case are close to previously reported cases of PEL-LL in terms of age, pleural and pericardial effusions, lack of tumor mass, and detected atypical lymphoid blasts in the effusion (Table 1, Table 2). Due to the fact that monoclonal lymphoma cells had not been detected in pleural effusion, pericardial and pleural effusion was thought to be associated with lymphoma, especially PEL-LL, and not DLBCL. In addition, the patient maintained complete remission after rituximab monotherapy without recurrence of pericardial or pleural effusion, and without treatment for heart failure or other condition for an extended period, which is also generally consistent with the clinical course of PEL-LL. Even if the disease had been DLBCL, this case is remarkable because monotherapy with rituximab is a suboptimal and noncurative treatment for DLBCL in elderly patients. However, it is quite difficult to diagnose from nonspecific symptoms and laboratory abnormalities. Considering Tables 1 and 2, the presence of neoplastic change in bone marrow, absence of monoclonal B cell in pleural effusion by flow cytometry, and chromosomal abnormality are inconsistent with the characteristics of PEL-LL. Hence, the diagnosis may be PEL-LL-like DLBCL rather than PEL-LL. Strictly speaking, a diagnosis of DLBCL or intravascular lymphoma can only be made in a broad sense. From this point of view, massive pericardial and pleural effusion including atypical lymphoid cells in the present case are quite interesting.

In conclusion, we experienced an elderly patient with DLBCL mimicking PEL-LL. This case suggests the need for a careful and detailed examination from the first observation when encountering patients with pericardial or pleural effusion and inclusion of hematological malignancy in the differential diagnosis.

\section{Statement of Ethics}

The article does not contain data to identify patients. The authors have no ethical conflicts to disclose.

\section{Disclosure Statement}

The authors state that they have no conflicts of interest.

\section{References}

1 Cesarman E, Chang Y, Moore PS, Said JW, Knowles DM: Kaposi's sarcoma-associated herpesvirus-like DNA sequences in AIDS-related body-cavity-based lymphomas. N Engl J Med 1995;332:1186-1191. Kim KH, Lee JH, Jeong HC, Kim GW, Song SH, Jung SY, Kim GI, Kim EK: A case of human herpes virus-8 unrelated primary effusion lymphoma-like lymphoma presented as pleural effusion. Tuberc Respir Dis (Seoul) 2012;73:336-341. 
Terasaki Y, Yamamoto H, Kiyokawa H, Okumura H, Saito K, Ichinohasama R, Ishida Y: Disappearance of malignant cells by effusion drainage alone in two patients with HHV-8-unrelated HIV-negative primary effusion lymphoma-like lymphoma. Int J Hematol 2011;94:279-284. Adiguzel C, Bozkurt SU, Kaygusuz I, Uzay A, Tecimer T, Bayik M: Human herpes virus 8-unrelated primary effusion lymphoma-like lymphoma: report of a rare case and review of the literature. APMIS 2009;117:222-229.

Nakamura H, Tsuta K, Nakagawa T, Hirai R, Ota Y: Human herpes virus 8-unrelated primary effusion lymphoma-like lymphoma in the pericardium: a case with latency type III Epstein-Barr virus infection showing good prognosis without chemotherapy. Pathol Res Pract 2015;211:1010-1013. Alexanian S, Said J, Lones M, Pullarkat ST: KSHV/HHV8-negative effusion-based lymphoma, a distinct entity associated with fluid overload states. Am J Surg Pathol 2013;37:241-249. Wu W, Youm W, Rezk SA, Zhao X: Human herpesvirus 8-unrelated primary effusion lymphoma-like lymphoma: report of a rare case and review of 54 cases in the literature. Am J Clin Pathol 2013;140:258-273.

Swerdlow SH, Campo E, Pileri SA, Harris NL, Stein H, Siebert R, Advani R, Ghielmini M, Salles GA, Zelenetz AD, Jaffe ES: The 2016 revision of the World Health Organization (WHO) classification of lymphoid neoplasms. Blood 2016;127:2375-2390.

Fan HB, Yang DL, Guo Y, Chen AS, Zhou MX, Wu JJ, Ma XJ, Li Z: Human herpes virus 8-unrelated primary effusion lymphoma-like lymphoma in a patient with hepatitis B virus-related liver cirrhosis: a case report. J Res Med Sci 2014;19:190-192.

10 Wu W, Liu J, Hong W: Human herpes virus 8-unrelated primary effusion lymphoma-like lymphoma diagnosed by fluorodeoxyglucose positron emission tomography/computer tomography and laparoscopy. Oncol Lett 2014;7:433-434.

-11 Oki M, Nanao T, Shinoda T, Tsuda A, Yasuda A, Seki T, Ozawa H, Nakamura N, Takagi A: Primary effusion lymphoma-like lymphoma in a patient with neurofibromatosis type 1. Tokai J Exp Clin Med 2016;41:123-129.

-12 Hermine O, Michel M, Buzyn-Veil A, Gessain A: Body-cavity-based lymphoma in an HIV-seronegative patient without Kaposi's sarcoma-associated herpesvirus-like DNA sequences. N Engl J Med 1996;334:272-273.

-13 Shimazaki M, Fujita M, Tsukamoto K, Matsuki T, Iwata M, Takahashi H, Doi A, Hyakkoku M, Yamauchi K, Genda S, Kikuiri T, Sakamoto T, Nojiri S, Ashie T: An unusual case of primary effusion lymphoma in a HIV-negative patient not pathogenetically associated with HHV8. Eur J Haematol 2003;71:62-67. Nonami A, Yokoyama T, Takeshita M, Ohshima K, Kubota A, Okamura S: Human herpes virus 8-negative primary effusion lymphoma (PEL) in a patient after repeated chylous ascites and chylothorax. Intern Med 2004;43:236-242.

15 Takao T, Kobayashi Y, Kuroda J, Omoto A, Nishimura T, Kamitsuji Y, Fukiya E, Nakamura C, Kimura S, Yoshikawa T: Rituximab is effective for human herpesvirus-8-negative primary effusion lymphoma with CD20 phenotype associated hepatitis C virus-related liver cirrhosis. Am J Hematol 2004;77:419420.

16 Youngster I, Vaisben E, Cohen H, Nassar F: An unusual cause of pleural effusion. Age Ageing 2006;35:94-96.

17 Terasaki Y, Okumura H, Saito K, Sato Y, Yoshino T, Ichinohasama R, Ishida Y: HHV-8/KSHV-negative and CD20-positive primary effusion lymphoma successfully treated by pleural drainage followed by chemotherapy containing rituximab. Intern Med 2008;47:2175-2178.

-18 Tsagarakis NJ, Argyrou A, Gortzolidis G, Kentrou N, Papadhimitriou SI, Tzanetou K, Kakiopoulos G, Papadimitriou KA, Skoumi D, Paterakis G: Report of an HIV and HHV-8 negative case of primary effusion lymphoma with idiopathic T4 lymphocytopenia. Int J Hematol 2009;90:94-98.

19 Wang T, Nava VE, Schechter GP, Lichy JH, Liu ML: Human herpes virus 8-unrelated primary effusion lymphoma-like lymphoma: a patient successfully treated with pleurodesis. J Clin Oncol 2011;29:e747e750.

20 Wu W, Youm W, Rezk SA, Zhao X: Human herpesvirus 8-unrelated primary effusion lymphoma-like lymphoma: report of a rare case and review of 54 cases in the literature. Am J Clin Pathol 2013;140:258-273.

-21 Kashiwagi T, Minagawa K, Kawano H, Hirata T, Kashiwagi S, Nakagawa Y, Kusaka S, Suzuki T, Inagaki T, Kishi M, Miwa N, Kimura S, Takechi M, Koide M, Iwai M, Katayama Y, Matsui T: HIV-negative, HHV-8unrelated primary effusion lymphoma-like lymphoma with genotypic infidelity and c-MYC expression. Ann Hematol 2014;93:1609-1610. 


\section{Case Reports in Oncology}

Usuda et al.: A Case of Diffuse Large B-Cell Lymphoma Mimicking Primary Effusion Lymphoma-Like Lymphoma

22 Shin J, Lee JO, Choe JY, Bang SM, Lee JS: Human herpesvirus 8-unrelated primary effusion lymphomalike lymphoma in an elderly Korean patient with a good response to rituximab plus cyclophosphamide, doxorubicin, vincristine, and prednisolone. Cancer Res Treat 2017;49:274-278.

-23 Yamazaki K, Toyonaga Y, Itokawa T, Koyama Y, Ishida Y: Primary effusion lymphoma-like lymphoma unrelated to human herpesvirus 8 with aggressive clinical course in patient receiving cyclosporine. J Clin Oncol 2013;31:e435-e438.

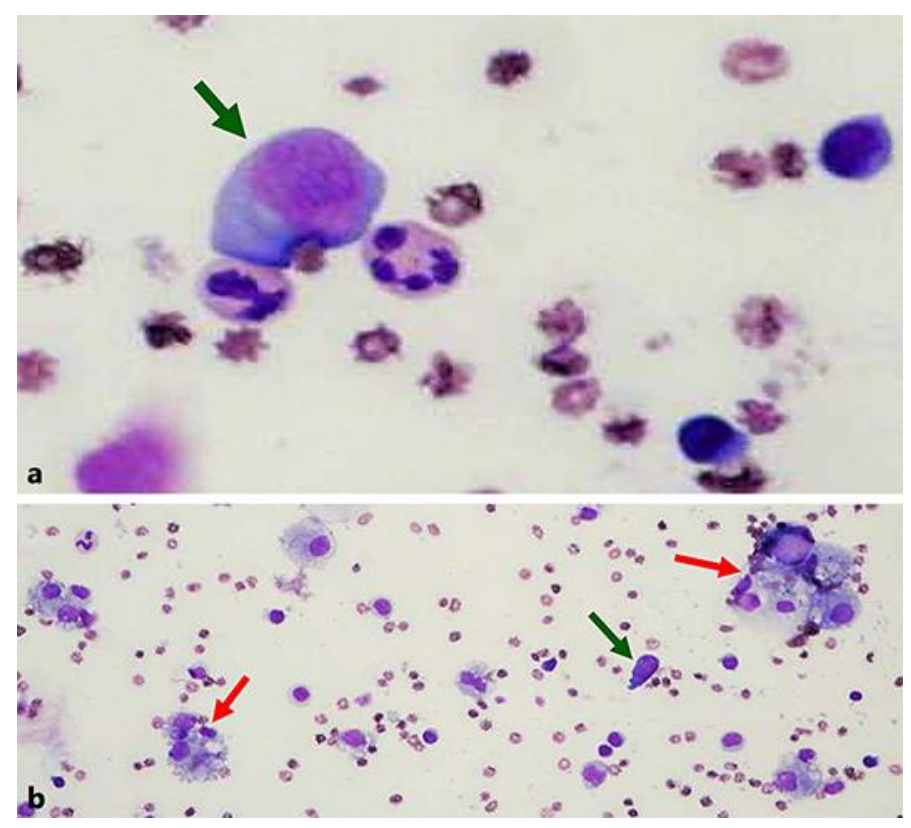

Fig. 1. Images of cytodiagnosis: pleural fluid. a Atypical cell is confirmed (green arrow). May-Giemsa staining. $\times 1,000$. b Atypical cell (green arrow) and hemophagocytosis (red arrows) are confirmed. May-Giemsa staining. $\times 400$. 


\section{Case Reports in Oncology}
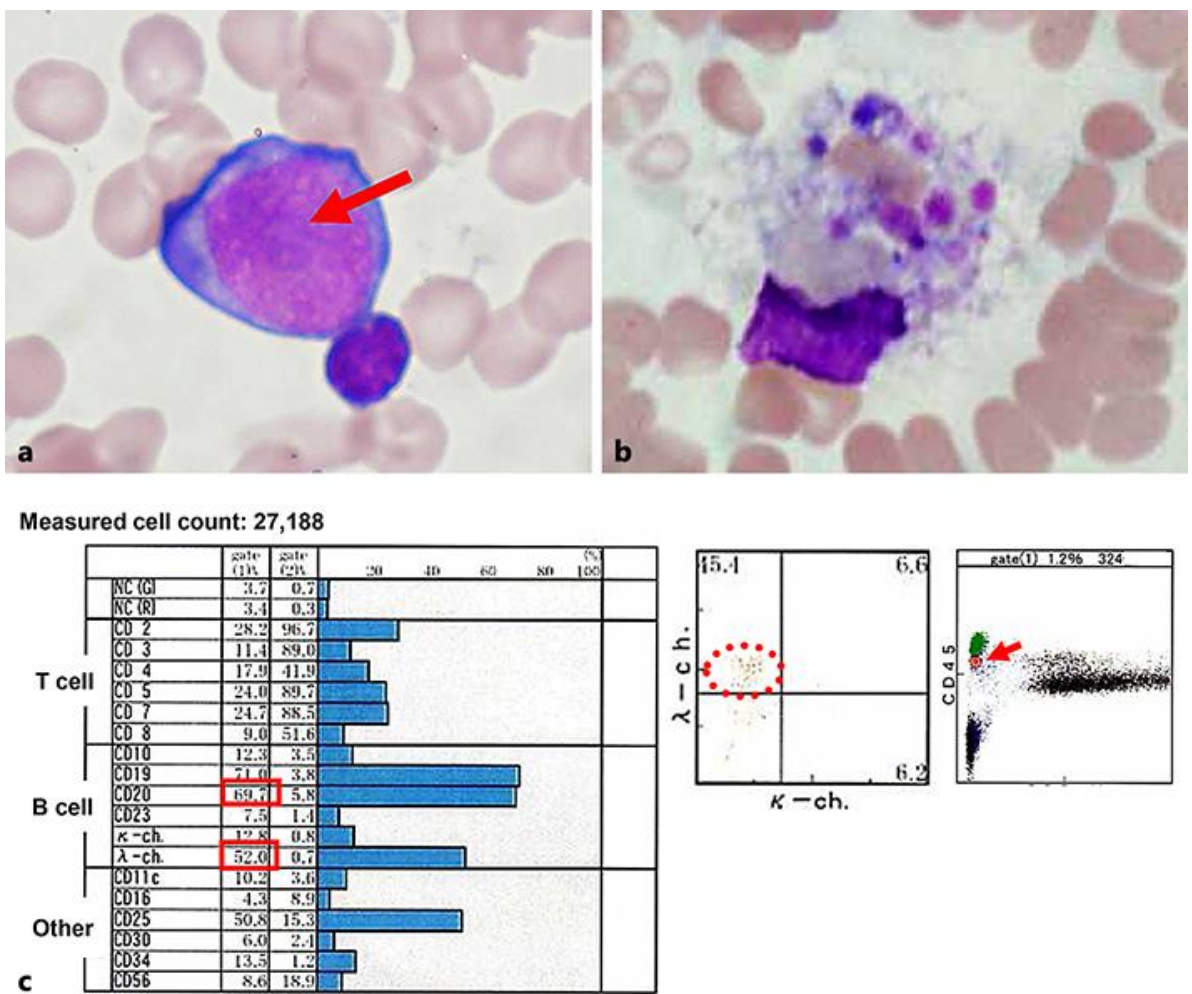

Fig. 2. Histopathological images and cell surface antigen analysis of bone marrow. a Histopathological image of the specimen. Atypical cells are confirmed (red arrow). May-Giemsa staining. $\times 1,000$. b Histopathological image of the specimen. Hemophagocytosis is confirmed. May-Giemsa staining. $\times 1,000$. c Cell surface antigen analysis of bone marrow cells. Analysis reveals strong deviation among cell surface of immunoglobulin light chain in B-lymphocyte fraction. Furthermore, the rate of CD20-positive cells is high, about $70 \%$. CD, cluster of differentiation. 


\section{Case Reports in Oncology}

Usuda et al.: A Case of Diffuse Large B-Cell Lymphoma Mimicking Primary Effusion
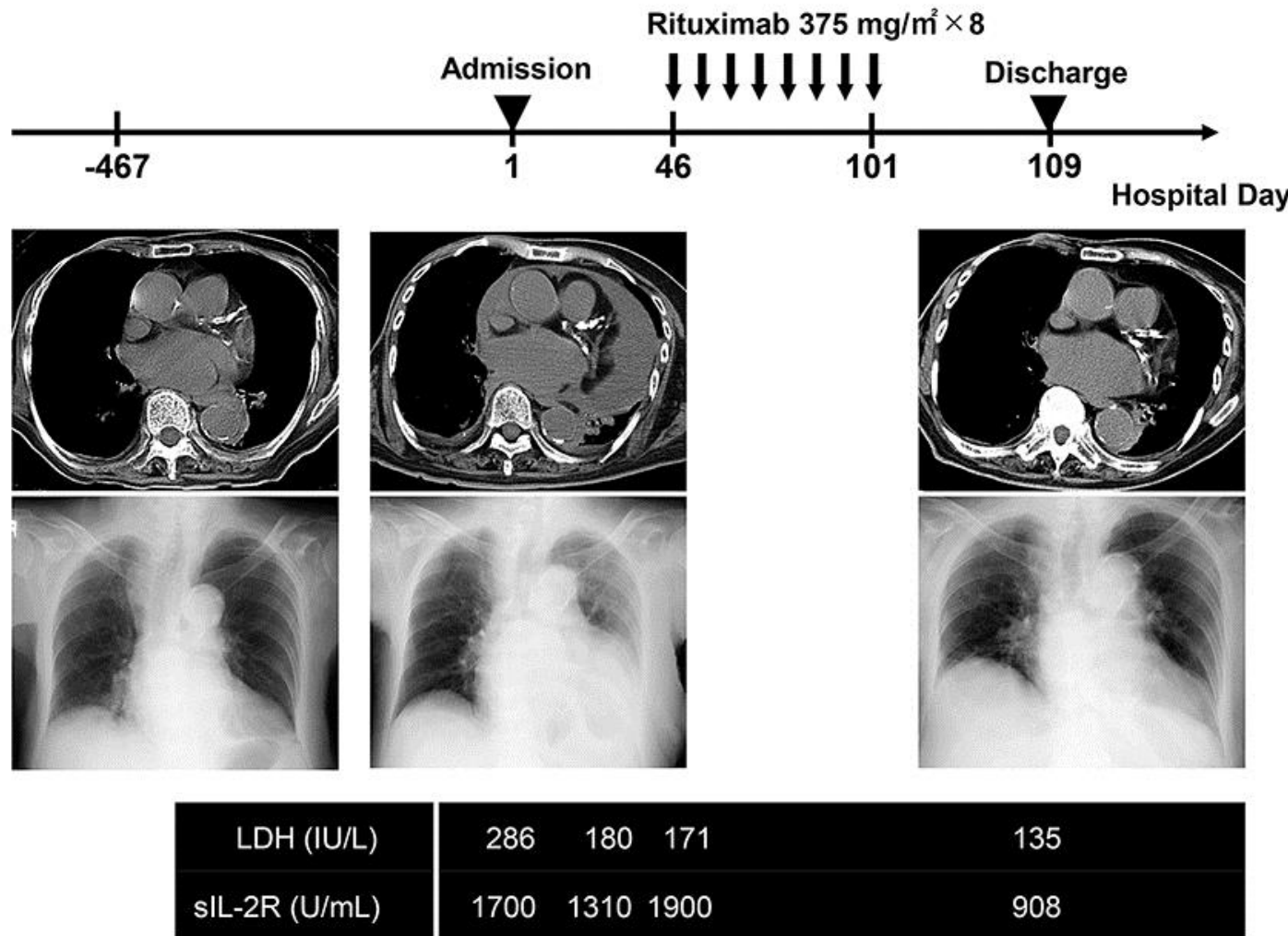

\section{$286 \quad 180 \quad 171$}

170013101900

135

908

Fig. 3. Clinical course of the patient. After diagnosis of diffuse large B-cell lymphoma, $375 \mathrm{mg} / \mathrm{m}^{2} \mathrm{rituximab}$ therapy, once per week, was started on day 46 of hospitalization. Afterwards, pleural effusion and the values of LDH and sIL-2R markedly decreased, and the patient was discharged on day 109 of hospitalization. $\mathrm{LDH}$, lactate dehydrogenase; sIL-2R, soluble interleukin-2 receptor. 


\section{Case Reports in Oncology}

\begin{tabular}{l|l} 
DOI: $10.1159 / 000484042$ & (C) 2017 The Author(s). Published by S. Karger AG, Basel
\end{tabular} www.karger.com/cro

Usuda et al.: A Case of Diffuse Large B-Cell Lymphoma Mimicking Primary Effusion Lymphoma-Like Lymphoma

Table 1. Reported cases of primary effusion lymphoma-like lymphoma including our case

\begin{tabular}{|c|c|c|c|c|c|c|c|c|c|c|c|c|c|}
\hline \multirow[t]{2}{*}{ Case } & \multirow{2}{*}{$\begin{array}{l}\text { Age, } \\
\text { years }\end{array}$} & \multirow[t]{2}{*}{ Sex } & \multirow[t]{2}{*}{ Symptoms } & \multirow[t]{2}{*}{ HBV } & \multirow[t]{2}{*}{$\mathrm{HCV}$} & \multirow[t]{2}{*}{ HIV } & \multirow[t]{2}{*}{ EBV } & \multirow[t]{2}{*}{ HHV-8 } & \multirow[t]{2}{*}{ HTLV-1 } & \multirow{2}{*}{$\begin{array}{l}\text { Serum } \\
\text { LDH, } \\
\text { U/L }\end{array}$} & \multirow{2}{*}{$\begin{array}{l}\text { Serum } \\
\text { sIL-2R, } \\
\mathrm{U} / \mathrm{mL}\end{array}$} & \multicolumn{2}{|l|}{ Pleural effusion } \\
\hline & & & & & & & & & & & & $\begin{array}{l}\text { detection } \\
\text { of atypical } \\
\text { lymphoid cells }\end{array}$ & $\begin{array}{l}\text { monoclonality } \\
\text { (flow } \\
\text { cytometry) }\end{array}$ \\
\hline 1 & 99 & $\mathrm{~F}$ & Hypoxemia & ND & - & - & - & - & ND & 169 & ND & + & + \\
\hline 2 & 52 & $\mathrm{~F}$ & ND & ND & ND & - & - & ND & ND & ND & ND & + & + \\
\hline 3 & 90 & $\mathrm{~F}$ & Orthopnea & - & - & - & - & - & - & 738 & 1,370 & + & + \\
\hline 4 & 32 & $\mathrm{~F}$ & $\begin{array}{l}\text { Abdominal distension, night } \\
\text { sweats }\end{array}$ & - & + & - & - & - & - & 2,344 & 7,090 & + & - \\
\hline 5 & 74 & $\mathrm{~F}$ & Dyspnea, edema of lower limbs & - & + & - & - & - & ND & 574 & 14,000 & + & + \\
\hline 6 & 88 & M & Dyspnea, weakness & - & - & - & - & - & ND & 670 & ND & + & ND \\
\hline 7 & 68 & M & Dyspnea & ND & - & - & - & - & ND & 230 & ND & + & + \\
\hline 8 & 77 & M & Dyspnea, edema of lower limbs & + & - & - & + & - & - & ND & ND & + & + \\
\hline 9 & 79 & M & Dyspnea & - & - & - & - & ND & ND & 114 & ND & + & + \\
\hline 10 & 65 & $\mathrm{~F}$ & $\begin{array}{l}\text { Cough, general fatigue, shortness } \\
\text { of breath }\end{array}$ & - & - & ND & - & - & ND & ND & ND & + & + \\
\hline 11 & 76 & M & $\begin{array}{l}\text { Cough, general fatigue, night } \\
\text { sweats }\end{array}$ & ND & - & - & - & - & - & 377 & 525 & + & + \\
\hline 12 & 77 & M & $\begin{array}{l}\text { Abdominal distension, pitting } \\
\text { edema of both lower limbs }\end{array}$ & - & - & - & - & - & ND & 393 & ND & + & ND \\
\hline 13 & 71 & $\mathrm{~F}$ & Abdominal distension & - & - & - & + & - & ND & 1,404 & 1,060 & + & + \\
\hline $\begin{array}{l}\text { Our } \\
\text { case }\end{array}$ & 93 & $\mathrm{~F}$ & $\begin{array}{l}\text { Hypotension, disturbance of } \\
\text { consciousness }\end{array}$ & 0 & ND & 0 & ND & ND & ND & 286 & 1,700 & + & - \\
\hline
\end{tabular}

"+" indicates that the data are positive or detected. “-" indicates that the data are negative or undetected. ND, not done or not described; HBV, hepatitis B virus; HCV, hepatitis C virus; HIV, human immunodeficiency virus; EBV, Epstein-Barr virus; HHV, human herpesvirus; HTLV, human T-cell leukemia virus; LDH, lactate dehydrogenase; sIL-2R, soluble interleukin-2 receptor. 


\section{Case Reports in Oncology}

\begin{tabular}{l|l} 
DOI: $10.1159 / 000484042$ & (C) 2017 The Author(s). Published by S. Karger AG, Basel
\end{tabular} www.karger.com/cro

Usuda et al.: A Case of Diffuse Large B-Cell Lymphoma Mimicking Primary Effusion

Lymphoma-Like Lymphoma

Table 2. Reported cases of primary effusion lymphoma-like lymphoma including our case (continued from Table 1)

\begin{tabular}{|c|c|c|c|c|c|c|c|}
\hline Case & $\begin{array}{l}\text { Bone } \\
\text { marrow } \\
\text { infiltration }\end{array}$ & Immunohistochemistry & $\begin{array}{l}\text { Chromosomal } \\
\text { abnormality }\end{array}$ & Site involved & Treatment & Outcome & Ref. \\
\hline 1 & - & $\begin{array}{l}\text { CD5, CD19, CD20, CD25, SmIgM, } \\
\text { SmIgD, Ig- } \lambda \text { light chain }\end{array}$ & + & Pleura, pericardium & Drainage & Alive, 16 months & 3 \\
\hline 2 & - & $\begin{array}{l}\text { CD19, CD20, CD22, CD } 45 \\
\text { DR antigen }\end{array}$ & + & Pleura, pericardium & Unknown & Unknown & 12 \\
\hline 3 & - & CD20, CD79a, bcl-2 & + & $\begin{array}{l}\text { Pleura, epicardium, } \\
\text { peritoneum }\end{array}$ & None & Died, 5 months & 13 \\
\hline 4 & - & CD10, CD19, CD20, HLA-DR & + & Pleura, peritoneum & THP-COP, PBSCT & Died, 22 months & 14 \\
\hline 5 & - & $\begin{array}{l}\text { CD19, CD20, CD25, CD45, } \\
\text { HLA-DR, SmIgG-к }\end{array}$ & + & $\begin{array}{l}\text { Pleura, pericardium, } \\
\text { peritoneum }\end{array}$ & THP-COP, rituximab & Alive, 26 months & 15 \\
\hline 6 & - & CD20, CD30, CD45, CD79a & ND & Pleura, pericardium & $\mathrm{R}-\mathrm{CHOP}$ & Alive, 9 months & 16 \\
\hline 7 & - & CD20, CD79a & - & Pleura & $\begin{array}{l}\text { Pleural drainage, } \\
\text { R-CHOP }\end{array}$ & Alive, 22 months & 17 \\
\hline 8 & - & $\begin{array}{l}\text { CD19, CD20, CD38, CD66, CD71, } \\
\text { cCD79a }\end{array}$ & + & Pleura & $\begin{array}{l}\text { Rituximab, cyclophos- } \\
\text { phamide, vincristine, } \\
\text { prednisolone }\end{array}$ & Alive, 3 months & 18 \\
\hline 9 & - & $\begin{array}{l}\text { CD20, CD45, CD79a, bcl-2, bcl-6, } \\
\text { MUM1 }\end{array}$ & + & Pleura & Drainage, pleurodesis & Alive, 55 months & 19 \\
\hline 10 & - & $\begin{array}{l}\text { CD19, CD20, CD38, CD79a, CD138, } \\
\text { MUM-1, PAX-5 }\end{array}$ & - & Pleura & $\begin{array}{l}\text { Rituximab, cyclophos- } \\
\text { phamide, vincristine, } \\
\text { prednisolone }\end{array}$ & Died, 5.5 months & 20 \\
\hline 11 & - & $\begin{array}{l}\text { CD19, CD20, CD30, CD79a, } \\
\text { Ig- } \lambda \text { light chain }\end{array}$ & + & Pleura & $\mathrm{R}-\mathrm{CHOP}$ & Alive, 18 months & 21 \\
\hline 12 & - & CD20, CD45, MUM-1 & - & Pleura, peritoneum & $\mathrm{R}-\mathrm{CHOP}$ & Alive, 15 months & 22 \\
\hline 13 & - & CD10, CD20, CD45, CD79a, bcl-6 & + & Pleura, peritoneum & $\mathrm{R}-\mathrm{CHOP}$ & Died, 16 months & 23 \\
\hline $\begin{array}{l}\text { Our } \\
\text { case }\end{array}$ & + & CD19, CD20, CD25, Ig- $\lambda$ light chain & - & $\begin{array}{l}\text { Bone marrow } \\
\text { (pleura? } \\
\text { pericardium?) }\end{array}$ & Rituximab & Alive, 28 months & \\
\hline
\end{tabular}

"+" indicates that the data are positive or detected. “-" indicates that the data are negative or undetected. ND, not done or not described; CD, cluster of differentiation; DR, D-related; HLA, human leukocyte antigen; MUM, multiple myeloma oncogene; PAX, paired box; EMA, epithelial membrane antigen; THP-COP, pirarubicin/cyclophosphamide/vincristine/prednisolone; PBSCT, peripheral blood stem cell transplantation; R-CHOP, rituximab-cyclophosphamide/doxorubicin/ vincristine/prednisone. 